\title{
The Development of Pattern Recognition via Clinical Experience: A Preliminary Study
}

\author{
Kazuhisa Matsui ${ }^{1}$, Kotaro Kawaguchi ${ }^{2}$ \\ ${ }^{1}$ Department of Rehabilitation, Gifu Junior College of Health Sciences, Japan. ${ }^{2}$ Department of Physical \\ Therapy, School of Rehabilitation Science, Hyogo University of Health Sciences, Japan
}

\section{ARTICLE INFO}

Received

: 26/06/2014

Accepted : :03/11/2014

Published : :01/12/2014

\section{KEYWORD}

Pattern recognition

Clinical experience

Quasi-Delphi technique

\section{ABSTRACT}

Introduction: Pattern recognition is a process whereby illness scripts are rapidly retrieved in response to attempting to recognize a clinical problem at hand. Although adeptness in clinical reasoning is not strictly related to years of clinical experience, pattern recognition as a part of such reasoning does require prior clinical experience if a repertoire of illness scripts is to be built up. Clinical experience provides the clinician with opportunities to link subjective description to objective findings and thus to appreciate the significance of changes in subjective findings. Objective: To investigate how pattern recognition develops through clinical experience. Method: 31 participants (10 undergraduate students and 21 clinicians) were surveyed via three rounds of questionnaires designed according to the Delphi technique to elucidate treatments for osteoarthritis of the knee and for Colles fracture after surgery. Consensus was considered achieved if $75 \%$ of the responses agreed. Result: For treatment of osteoarthritis of the knee, 72 items proposed by the students converged to 20 items, and 129 items proposed by the clinicians converged to 41 . For postoperative care of Colles fracture, 41 items proposed by the students were reduced to 19 items while the clinicians honed 88 items down to 35 through three rounds of survey. Conclusion: The quasi-Delphi did enable both students and clinicians to achieve consensus. Whereas the students came up with relatively vague items, the clinicians described concrete problems that patients encounter. Such differences suggest instances of narrative and diagnostic reasoning that might be incorporated into physical therapy education.

(C) Medical Education Department, School of Medical Sciences, Universiti Sains Malaysia. All rights reserved.

CORRESPONDING AUTHOR: Kazuhisa Matsui, 2-92 Higashi-Uzura, Gifu, Gifu, JAPAN 500-8281.

Email: matsui@bz04.plala.or.jp

\section{Introduction}

An experienced clinician, when examining a patient, typically uses "illness scripts" in conceptualizing the patient's problem. An illness script is a specific conception in the mind of the clinician to be matched against basic information about the patient, the patient's complaints, pathophysiological signs and symptoms, factors contributing to the illness, and family history (1). When an illness script matches the empirical situation at hand, the patient's problem can often be quickly recognized and action efficiently taken. Illness scripts progressively accumulate in the mind of a clinician through clinical experience (2). The clinician eventually becomes able, when exposed to a given clinical picture, to automatically recall a relevant illness script to 
initiate a focused inquiry in order to corroborate or refute a specific clinical hypothesis (3).

Pattern recognition is a process whereby illness scripts are rapidly retrieved in response to attempting to recognize a clinical problem at hand (4). This process requires the clinician to have built up a repertoire of illness scripts. It is a non-analytic form of reasoning, usually unconscious, whereby salient clinical features observed are recognized as similar to a specific previous experience (5). Patterns recognized involve syndromes, interventions, and pathobiological and psychosocial factors (6). Pattern recognition clearly excels over deliberative deductive reasoning in efficiently arriving at correct diagnoses (4). Although adeptness in clinical reasoning is not strictly related to years of clinical experience, pattern recognition as a part of such reasoning does require prior clinical experience if a repertoire of illness scripts is to be built up. Among other things, clinical experience provides the clinician with opportunities to link subjective description to objective findings and thus to appreciate the significance of changes in subjective findings. Therefore we hypothesised that subjective findings of pattern recognition in clinicians develop via clinical experience and the aspects of objective findings would be influenced by the subjective findings. The purpose of this study was to learn more about how physiotherapists acquire pattern recognition skills through clinical experience.

With the Delphi method, opinions and observations of members in a group are made to converge into a sophisticated consensus through an iterative use of questionnaires (7). The Delphi technique has four noteworthy characteristics: anonymity, sequential questionnaires, feedback, and distribution of answers to the group (8). This method has been used to achieve consensus in academic areas, social problems, education, medicine, and various other fields.

Clinical application of the Delphi technique can be found in the musculoskeletal area (9-14). Such studies achieved consensus after three to four rounds of questionnaires.
In a qualitative study, veteran physiotherapists frequently made decisions based on past professional experience, a resource unavailable to young physiotherapists, who had to depend more on reflection before acting (15). In a comparison between medical students and physicians, diagnostic accuracy was found to be related to clinical experience (16). In an examination designed to test skill in pattern recognition, senior surgical residents performed better than did medical students (17). These studies suggest that clinical experience may be necessary, if not sufficient, to develop pattern recognition of patients' problems. To what extent can pattern recognition be inculcated in novices? One way to approach this question would be to examine how an iterative approach such as the Delphi method yields a different kind of consensus in novices than in experienced clinicians.

\section{Method}

This study was approved by ethics committee of Hyogo University of Health Sciences. Three rounds of a quasi-Delphi technique were conducted to foster convergence in both the clinician and the student groups. The first round consisted of soliciting items to consider regarding osteoarthritis of the knee (OAK) and postoperative care of Colle's fracture (CFP), both conditions seen frequently in Japanese clinics and hospitals. Only items based on the disorders themselves were recorded. They were classified into subjective items, objective items and contributing factors, and then edited to fit into a questionnaire to be used in the second and third rounds. For each item, a five-degree Likert scale of (i) strongly disagree, (ii) disagree, (iii) undecided, (iv) agree and (v) strongly agree was used, and a tally of responses to that item in the previous round was displayed with the item. To avoid extraneous effects during the period of the three rounds, the participants were instructed to not discuss or study any topics related to the questionnaire.

Consensus on an item was deemed to have been achieved when more than $75 \%$ of the participants in a group indicated "agree" or "strongly agree" 
in the third round. Percent agreement was calculated for each item by numerically weighting the responses (strongly disagree $=1$, disagree $=2$, undecided $=3$, agree $=4$, and strongly agree $=5$ ) and dividing the sum of the weighted responses of "agree" and "strongly agree” by the sum of all the weighted responses.

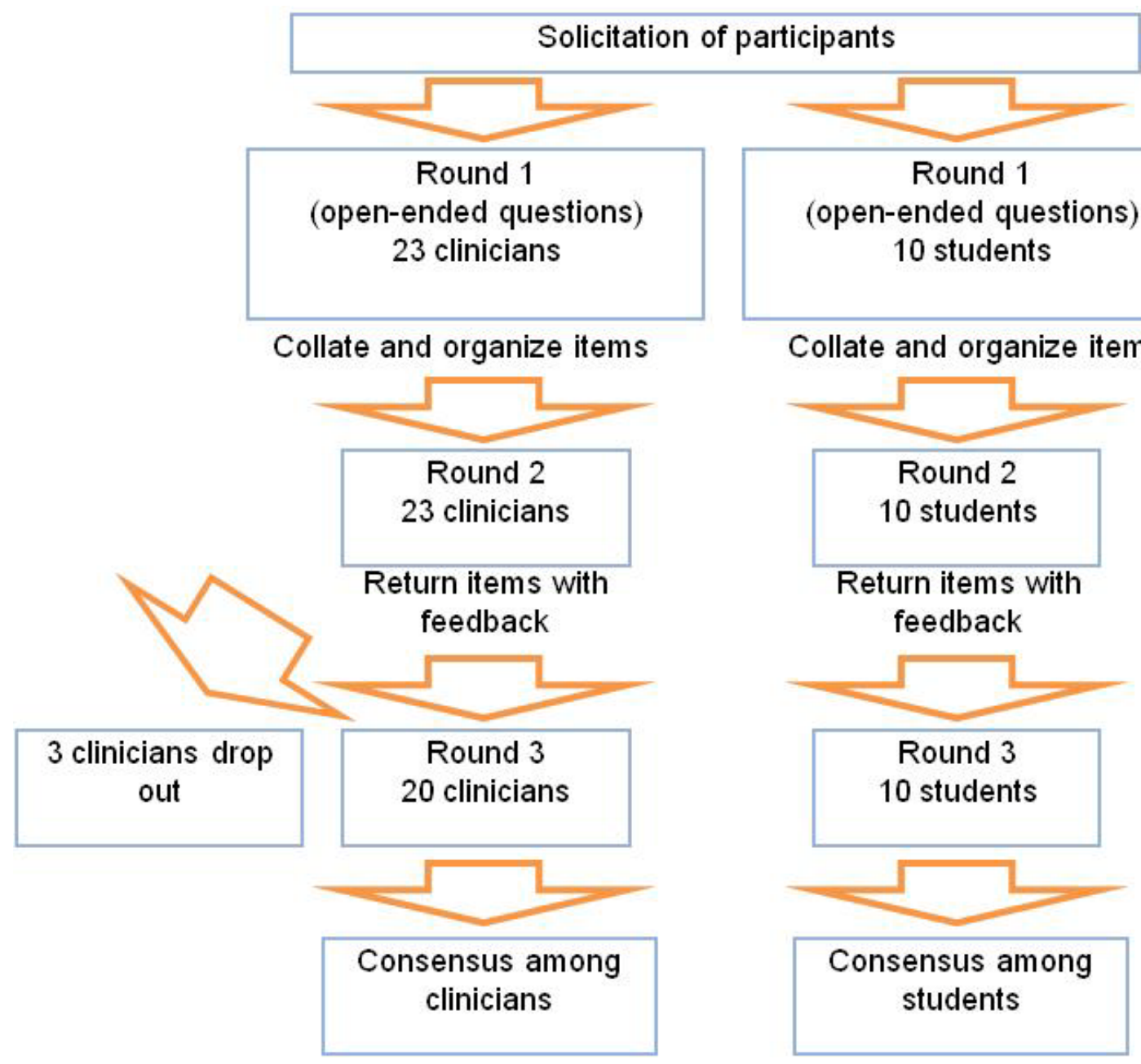

Figure 1: Iterative process of three sequential surveys.

\section{Result}

Three clinicians dropped out of the final round, so the response rate for the questionnaire was $100 \%$ for the students and $87 \%$ for the clinicians. In the first round, the students generated 72 items for OAK and 41 items for CFP, while the clinicians came up with 129 items for OAK and 88 items for CFP. After the third round, the students achieved consensus on 20 items for OAK and 19 items for CFP, while the clinicians reached consensus on 40 items for OAK and 35 for CFP (Figure 2).
The students reached consensus on six of their subjective items for OAK and on seven subjective items for CFP. The clinicians achieved agreement on 14 of their subjective items for OAK and on 14 for CFP. Among their objective items, the students had consensus on 11 items for OAK and on nine for CFP. The clinicians reached consensus on 21 and 18 of their objective items for OAK and CFP, respectively. As far as contributing factors are concerned, the students agreed on three items for OAK and on one for CFP, and the clinicians on five items for OAK and on three for CFP. 
For OAK, the clinicians identified and agreed on many items related to various pathologies whereas the students limited themselves more to functional difficulties (Table 1). For CFP, the students tended toward kinesiological descriptions in their items and their subjective findings were expressed in relatively colloquial terms (Table 2).

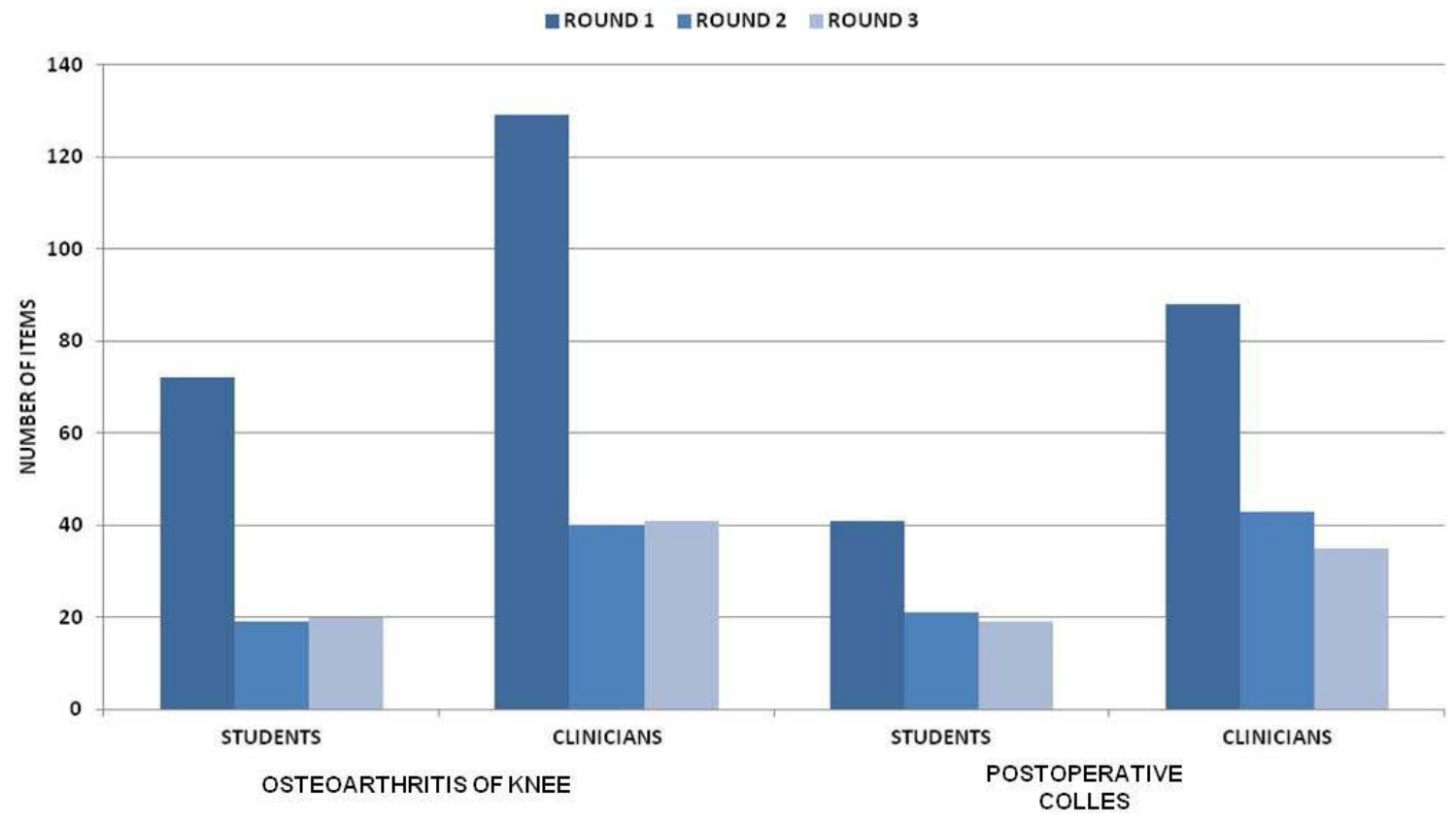

Figure 2: Convergence of items over three successive rounds. Round 1 was solicitation of items relevant to osteoarthritis of the knee or postoperative care of Colles fracture. Rounds 2 and 3 indicate number of items for which $75 \%$ agreement was achieved. 
Table 1: Items of osteoarthritis of the knee identified by clinicians and by students. (VMO: vastus medialis obliquus, ITB: iliotibial band, FTA: femorotibial angle)

Clinicians Subjective items

\begin{tabular}{|c|c|c|c|c|c|}
\hline & & \multicolumn{2}{|c|}{ Round 2 } & \multicolumn{2}{|c|}{ Round 3} \\
\hline & & $\begin{array}{l}\text { Composite } \\
\text { score }\end{array}$ & $\begin{array}{l}\% \text { of } \\
\text { consensus }\end{array}$ & $\begin{array}{l}\text { Composite } \\
\text { score }\end{array}$ & $\begin{array}{l}\% \text { of } \\
\text { consensus }\end{array}$ \\
\hline \multirow{2}{*}{$\begin{array}{l}\text { Onset of } \\
\text { Symptom } \\
\text { Area of Pain }\end{array}$} & Spontaneous onset & 83 & 69.88 & 75 & 81.33 \\
\hline & $\begin{array}{l}\text { Medial aspect of knee } \\
\text { Anterior aspect of knee } \\
\text { Posterior aspect of knee }\end{array}$ & $\begin{array}{l}96 \\
84 \\
86\end{array}$ & $\begin{array}{l}94.79 \\
69.05 \\
80.23\end{array}$ & $\begin{array}{l}83 \\
76 \\
75\end{array}$ & $\begin{array}{c}100 \\
80.26 \\
80\end{array}$ \\
\hline \multirow[t]{2}{*}{$\begin{array}{l}\text { Aggravating } \\
\text { factors }\end{array}$} & Going up stairs & 102 & 100 & 85 & 100 \\
\hline & $\begin{array}{l}\text { Walking on slope } \\
\text { Sit-to-stand/sit down } \\
\text { Initiating gait } \\
\text { Weight bearing } \\
\text { Full squatting }\end{array}$ & $\begin{array}{c}93 \\
98 \\
100 \\
98 \\
92\end{array}$ & $\begin{array}{c}87.1 \\
96.94 \\
100 \\
97.96 \\
80.43\end{array}$ & $\begin{array}{l}80 \\
84 \\
81 \\
85 \\
79\end{array}$ & $\begin{array}{c}100 \\
100 \\
92.59 \\
96.47 \\
93.67\end{array}$ \\
\hline \multirow[t]{2}{*}{$\begin{array}{l}\text { Activity } \\
\text { restrictions }\end{array}$} & Cannot sit on heels & 100 & 97 & 80 & 92.5 \\
\hline & Difficulty to do full squat & 99 & 96.97 & 83 & 92.77 \\
\hline
\end{tabular}

\begin{tabular}{|c|c|c|c|c|c|}
\hline & \multirow{2}{*}{ Objectiveiter } & \multicolumn{2}{|c|}{ Round 2 } & \multicolumn{2}{|c|}{ Round 3} \\
\hline & & $\begin{array}{l}\text { Composite } \\
\text { score }\end{array}$ & $\begin{array}{c}\% \text { of } \\
\text { consensus }\end{array}$ & $\begin{array}{c}\text { Composite } \\
\text { score }\end{array}$ & $\begin{array}{l}\% \text { of } \\
\text { consensus }\end{array}$ \\
\hline Swelling & Swollen knee & 95 & 93.68 & 77 & 84.42 \\
\hline Muscle atrophy & Vastas medialis & $\begin{array}{c}100 \\
90\end{array}$ & $\begin{array}{c}97 \\
8778\end{array}$ & $\begin{array}{l}87 \\
81\end{array}$ & 100 \\
\hline Joint deformity & $\begin{array}{l}\text { Varus deformity of knee } \\
\text { Valgus deformity of knee }\end{array}$ & $\begin{array}{l}99 \\
92\end{array}$ & $\begin{array}{l}96.97 \\
86.96\end{array}$ & $\begin{array}{l}84 \\
78\end{array}$ & $\begin{array}{l}96.43 \\
80.77\end{array}$ \\
\hline Gait & Lateral thrust & 97 & 93.81 & 83 & 96.39 \\
\hline \multirow{3}{*}{$\begin{array}{l}\text { Tenderness } \\
\text { Muscle } \\
\text { tightness }\end{array}$} & Over tibiofemoral joint space & 99 & 93.94 & 81 & 88.89 \\
\hline & Vastus lateralis & 91 & 90.11 & 77 & 84.42 \\
\hline & Tliotibial band & 94 & 93.62 & 78 & 84.62 \\
\hline Hydrarthrosis & $\begin{array}{l}\text { Positive findings of } \\
\text { Ballottement test }\end{array}$ & 92 & 81.52 & 77 & 84.42 \\
\hline \multirow{3}{*}{$\begin{array}{l}\text { Restriction of } \\
\text { the raange of } \\
\text { motion }\end{array}$} & $\begin{array}{l}\text { Tibiofemoral joint flexion } \\
\text { restriction }\end{array}$ & 100 & 100 & 83 & 100 \\
\hline & $\begin{array}{l}\text { Tibiofemoral joint extension } \\
\text { restriction }\end{array}$ & 101 & 100 & 83 & 92.77 \\
\hline & $\begin{array}{l}\text { Patellofemoral joint } \\
\text { restriction }\end{array}$ & 95 & 93.68 & 79 & 88.61 \\
\hline \multirow{8}{*}{$\begin{array}{l}\text { Muscle strength } \\
\text { Images }\end{array}$} & Weakness of quadriceps & 90 & 80 & 78 & 84.62 \\
\hline & Osteophyte in radiograph & 99 & 100 & 83 & 100 \\
\hline & Osteosclerosis in X-ray & 98 & 96.94 & 83 & 100 \\
\hline & Irregular articular surface & 90 & 83.33 & 79 & 92.41 \\
\hline & $\begin{array}{l}\text { Knee joint space narrowing in } \\
\text { X-ray }\end{array}$ & 98 & 100 & 84 & 100 \\
\hline & $\begin{array}{l}\text { Medial knee joint space } \\
\text { narrowing }\end{array}$ & 97 & 100 & 84 & 100 \\
\hline & $\begin{array}{l}\text { Varus deformity of knee in X- } \\
\text { fay }\end{array}$ & 94 & 93.62 & 78 & 88.46 \\
\hline & $\begin{array}{l}\text { Increased/decreased FTA } \\
\text { angle }\end{array}$ & 94 & 90.43 & 79 & 88.61 \\
\hline
\end{tabular}

\begin{tabular}{|c|c|c|c|c|c|}
\hline & \multicolumn{5}{|l|}{ Contributing factors } \\
\hline & & \multicolumn{2}{|c|}{ Round 2 } & \multicolumn{2}{|c|}{ Round 3 } \\
\hline & & $\begin{array}{l}\text { Composite } \\
\text { score }\end{array}$ & $\begin{array}{c}\% \text { of } \\
\text { consensus }\end{array}$ & $\begin{array}{l}\text { Composite } \\
\text { score }\end{array}$ & $\begin{array}{c}\% \text { of } \\
\text { consensus }\end{array}$ \\
\hline \multirow{6}{*}{$\begin{array}{l}\text { Age } \\
\text { Gender } \\
\text { Obesity } \\
\text { Muscle } \\
\text { weakness }\end{array}$} & Over 50 years old & 85 & 72.94 & 77 & 85.71 \\
\hline & & & & & \\
\hline & & 96 & 96.88 & 82 & 96.34 \\
\hline & Trunk and lower extremity & 89 & 86.52 & 76 & 84.21 \\
\hline & Gluteus maximus & 88 & 79.55 & 77 & 84.42 \\
\hline & Gluteus medius & 88 & 82.95 & 77 & 88.31 \\
\hline
\end{tabular}

Students

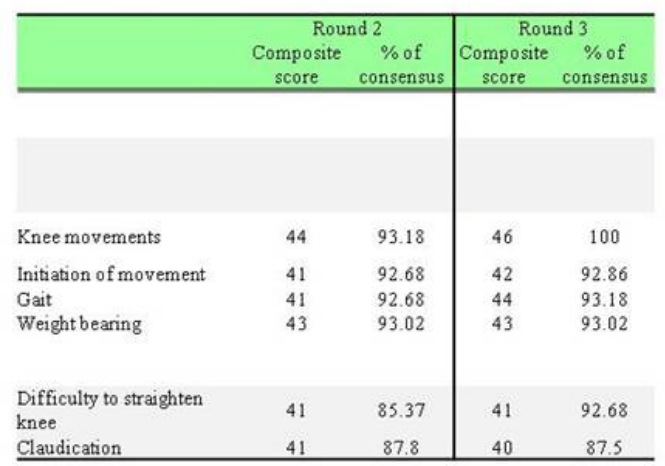

Claudication

\begin{tabular}{ll|ll}
41 & 87.8 & 40 & 87.5 \\
\hline
\end{tabular}
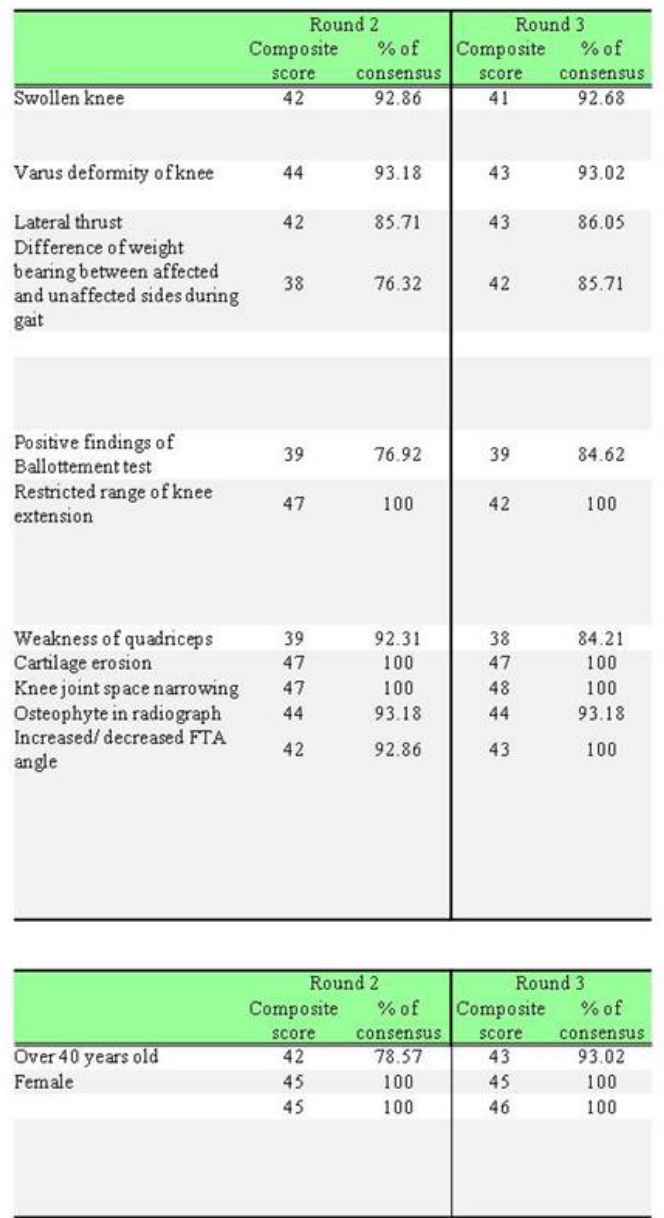
Table 2: The Findings in post surgery of Colle's fracture in student and clinician groups

Clinicians

Onset of histon

\begin{tabular}{|c|c|c|c|c|c|}
\hline \multirow[b]{3}{*}{ Cause of injury } & \multirow[b]{3}{*}{ Breaking fall with hand } & \multicolumn{2}{|c|}{$\begin{array}{c}\text { Round 2 } \\
\text { Composite\% of }\end{array}$} & \multicolumn{2}{|c|}{$\begin{array}{c}\text { Round } 3 \\
\text { Composite } \% \text { of }\end{array}$} \\
\hline & & score & consensus & score & consensus \\
\hline & & 99 & 94.95 & 86 & 100 \\
\hline & \multicolumn{5}{|l|}{ Subjective items } \\
\hline & & \multicolumn{2}{|c|}{$\begin{array}{c}\text { Round } 2 \\
\text { Composite\% of }\end{array}$} & \multicolumn{2}{|c|}{$\begin{array}{c}\text { Round } 3 \\
\text { Composite\% of }\end{array}$} \\
\hline & & & consensus & score & consensus \\
\hline \multirow[t]{3}{*}{ Area of pain } & $\begin{array}{l}\text { Distal head of radius in acute } \\
\text { stage }\end{array}$ & 99 & 97.98 & 83 & 96.39 \\
\hline & Around wrist & 98 & 96.94 & 81 & 96.3 \\
\hline & Dorsal aspect of wrist & 92 & 90.22 & 81 & 96.3 \\
\hline \multirow[t]{2}{*}{ Area of effusion } & Distal forearm & 90 & 87.78 & 78 & 88.46 \\
\hline & Around distal radial head & 92 & 90.22 & 76 & 84.21 \\
\hline \multicolumn{6}{|l|}{ Resting pain } \\
\hline \multirow[t]{4}{*}{$\begin{array}{l}\text { Aggravcating } \\
\text { factors }\end{array}$} & Moving wrist & 96 & 100 & 82 & 100 \\
\hline & $\begin{array}{l}\text { Turning hand over } \\
\text { (pronation/supination) }\end{array}$ & 95 & 100 & 81 & 96.3 \\
\hline & Placing hand on a flat surface & 96 & 100 & 85 & 100 \\
\hline & Carrying a heavy object & 93 & 93.55 & 80 & 96.25 \\
\hline \multirow[t]{3}{*}{$\begin{array}{l}\text { Feeling of } \\
\text { Weakness }\end{array}$} & Around wrist & 94 & 93.62 & 76 & 84.21 \\
\hline & Grip power & 98 & 93.88 & 82 & 96.34 \\
\hline & Pinch strength & 92 & 83.7 & 78 & 88.46 \\
\hline \multirow[t]{2}{*}{ The other } & Difficult to move wrist & 94 & 96.81 & 79 & 96.2 \\
\hline & $\begin{array}{l}\text { Oedema around distal radial } \\
\text { head }\end{array}$ & 92 & 90.22 & 76 & 84.21 \\
\hline
\end{tabular}

\section{Objective items}

\begin{tabular}{|c|c|c|c|c|c|}
\hline & & \multicolumn{2}{|c|}{$\begin{array}{c}\text { Round 2 } \\
\text { Composite\% of }\end{array}$} & \multicolumn{2}{|c|}{$\begin{array}{c}\text { Round } 3 \\
\text { Composite\% of }\end{array}$} \\
\hline & & score & consensus & score & consensus \\
\hline \multirow[t]{2}{*}{ Swelling } & Distal radius in acute stage & 100 & 100 & 82 & 96.34 \\
\hline & Forearm to fingers & 90 & 83.33 & 76 & 80.26 \\
\hline Heat & Distal radius in acute stage & 96 & 94.79 & 81 & 92.59 \\
\hline \multirow[t]{3}{*}{ Palpation } & Bony tendemess & 94 & 87.23 & 81 & 96.3 \\
\hline & Malalignment of carpal bones & 89 & 83.15 & 79 & 88.61 \\
\hline & $\begin{array}{l}\text { Change in movement axis of } \\
\text { wrist and forearm movements }\end{array}$ & 86 & 75.58 & 76 & 84.21 \\
\hline \multirow[t]{7}{*}{$\begin{array}{l}\text { Restrictiono of the } \\
\text { range of motion }\end{array}$} & $\begin{array}{l}\text { Active range of wrist (dorsal } \\
\text { and volar flexion) and } \\
\text { forearm (pronation and } \\
\text { supination) }\end{array}$ & 93 & 96.77 & 83 & 96.39 \\
\hline & Volar flexion & 98 & 100 & 81 & 96.3 \\
\hline & Dorsiflexion & 93 & 91.4 & 77 & 90.91 \\
\hline & Ulnar deviation & 90 & 87.78 & 75 & 80 \\
\hline & Supination & 94 & 96.81 & 79 & 92.41 \\
\hline & Pronation & 91 & 93.41 & 76 & 84.21 \\
\hline & Accessory movement & 91 & 90.11 & 77 & 88.31 \\
\hline \multirow[t]{3}{*}{ Muscle strength } & Weakness of hand and wrist & 95 & 93.68 & 82 & 96.34 \\
\hline & $\begin{array}{l}\text { Intrinsic muscle weakness of } \\
\text { hand and fingers }\end{array}$ & 85 & 76.47 & 76 & 84.21 \\
\hline & Decreased grip strength & 96 & 100 & 83 & 100 \\
\hline \multirow[t]{2}{*}{ Images } & $\begin{array}{l}\text { Fracture line on distal radius } \\
\text { in X-ray }\end{array}$ & 101 & 97.03 & 85 & 100 \\
\hline & $\begin{array}{l}\text { Dinner-fork deformity in X. } \\
\text { ray }\end{array}$ & 97 & 93.81 & 84 & 100 \\
\hline
\end{tabular}

\begin{tabular}{|c|c|c|c|c|}
\hline & \multicolumn{2}{|c|}{$\begin{array}{c}\text { Round } 2 \\
\text { Composite\% of }\end{array}$} & \multicolumn{2}{|c|}{$\begin{array}{c}\text { Round } 3 \\
\text { Composite\% of }\end{array}$} \\
\hline & score & consensus & score & consensu \\
\hline Osteoporosis & 97 & 90.72 & 84 & 92.86 \\
\hline Elderly & 93 & 90.32 & 80 & 88.75 \\
\hline
\end{tabular}

Comorbidity

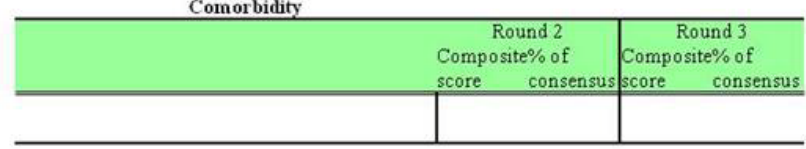

Students

\begin{tabular}{|c|c|c|c|c|}
\hline & \multicolumn{2}{|c|}{ Round 2} & \multicolumn{2}{|c|}{ Round 3} \\
\hline & $\begin{array}{c}\text { Composi } \\
\text { score }\end{array}$ & $\begin{array}{l}\text { te } \% \text { of } \\
\text { consensus }\end{array}$ & $\begin{array}{c}\text { Composite } \\
\text { score }\end{array}$ & $\begin{array}{c}\% \text { of } \\
\text { consensus }\end{array}$ \\
\hline $\begin{array}{l}\text { Breaking fall with } \\
\text { hand }\end{array}$ & 49 & 100 & 49 & 100 \\
\hline & $\begin{array}{r}\mathrm{Ro} \\
\text { Composi } \\
\text { score }\end{array}$ & $\begin{array}{l}\text { und } 2 \\
\text { te } \% \text { of } \\
\text { consensus }\end{array}$ & $\begin{array}{r}\text { Rour } \\
\text { Composite } \\
\text { score }\end{array}$ & $\begin{array}{l}\text { ind } 3 \\
\quad \% \text { of } \\
\text { consensus }\end{array}$ \\
\hline Pain in wrist & & 95.45 & 46 & 93.48 \\
\hline $\begin{array}{l}\text { Wrist } \\
\text { Forearm }\end{array}$ & & $\begin{array}{l}87.8 \\
92.68\end{array}$ & $\begin{array}{l}43 \\
41\end{array}$ & $\begin{array}{l}93.02 \\
92.68\end{array}$ \\
\hline Moving wrist & 46 & 100 & 46 & 93.48 \\
\hline Moving forearm & 43 & 100 & 43 & 93.02 \\
\hline Dorsiflexion of wrist & 45 & 93.33 & 45 & 100 \\
\hline $\begin{array}{l}\text { Restricted active } \\
\text { wrist range }\end{array}$ & 46 & 100 & 46 & 100 \\
\hline
\end{tabular}
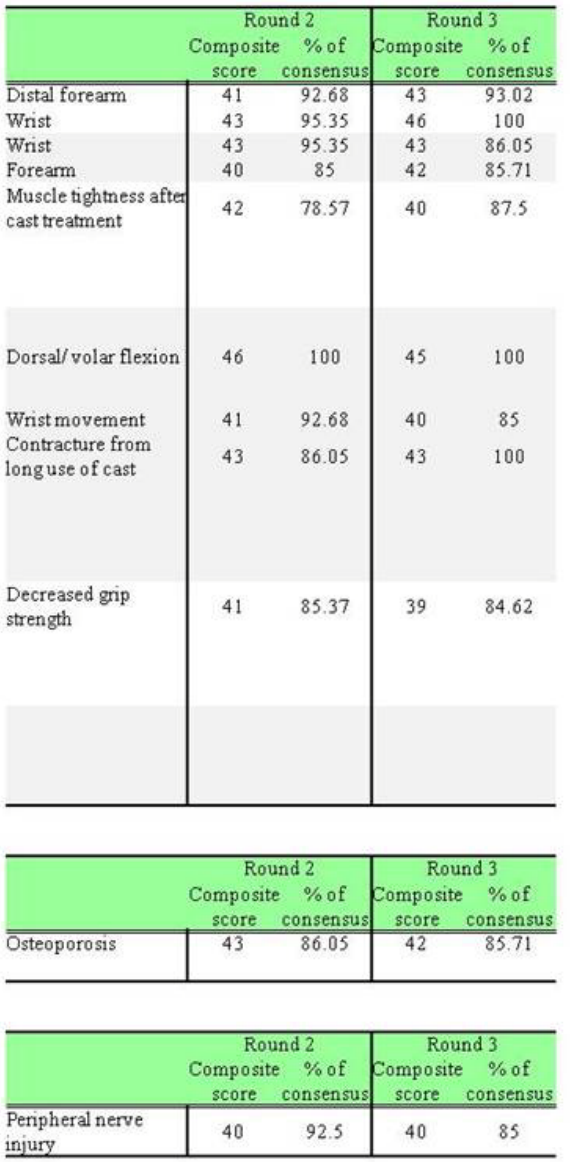


\section{Discussion}

In this study, we attempted to find out an effect of clinical experience by using a Delphi method with both experienced and inexperienced people. Consensus concerning pattern recognition was achieved in both groups over three rounds of query. The students invariably produced fewer findings for pattern recognition than did the experienced clinicians. The reason why the fourth-year undergraduate students were chosen as control group was because they acquired the standard knowledge with less clinical experience as physiotherapists.

The clinicians' items concerning subjective findings described patients' complaints more specifically than did corresponding items generated by the students. This likely reflects experience that informed the clinicians of troubles that patients typically face in their daily lives. Certain movements appear to have been recognized among the clinicians as common problems; using narrative reasoning, they would interpret these movements in terms of how patients perceived their own disorders (19). Narrative reasoning has been observed to be a feature in the interview process of experts (20). For patients with OAK, the clinicians suggested looking for pain in specific situations such as ascent or descent of stairs, whereas the students queried about pain in more general circumstances of motion, as during gait. For CFP, clinicians included feeling of weakness in hand grip and difficulty of placing the hand onto a flat surface. The students, for their part, tended to describe subjective findings in terms of joint motions and positions, such as "pain during dorsiflexion of the affected wrist". Clinical experts can use specific chunks of information that they associate with a given clinical condition to infer the possibility of concrete problems (3). One reason for the students generating fewer items on pain might be attributable to their inexperience with actual signs and symptoms, requiring them to resort to consciously associating textbook knowledge with what little they have seen in the clinic (21).
For objective findings in OAK, the students limited themselves to tibiofemoral joint problems and came up with descriptions similar to their subjective findings. The clinicians included patellofemoral difficulties along with tibiofemoral joint problems as well as radiographic findings in OAK. Both groups indicated weakness of the quadriceps as important to consider. Functional aspects of the knee have been found to merit attention more than image findings in OAK (22). Various objective findings put forth by the clinicians address this problem.

Whereas the clinicians specified a number of passive physiological movements for examining CFP patients, the students came up with relatively few objective examinations, likely a consequence of their lack of clinical experience. The main difference of subjective findings between students and clinicians may likewise have resulted from the disparity of experience in interviewing patients. Students would likely have difficulty eliciting information from patients via narrative reasoning. Most of the items generated for CFP by the students related to restricted range of movement, perhaps because of the period of cast immobilization of the wrist that one would expect. The students would thus focus on the secondary effects of wrist immobilization rather than features of CFP itself. Clinicians might be able to reassess functional movements which were elicited throughout interviewing since they can predict how the symptom interrupts the typical movements.

Both groups appeared to have assumed CFP patients to be older than what one might expect from epidemiologic studies. The age of CFP patients is typically about 30 to 60 years old (23). In one study, mean age of distal radial fracture was approximately 23 years for men and 48 years for women (24). Another article mentioned over 50 years old as prevalent for CFP, with a close relationship between osteoporosis and CFP (25).

Some of the clinician's items for OAK reflected the Japanese custom of sitting cross-legged on the floor. Sitting on the heels (seiza) was 
included in a subjective item. Medial knee pain and varus deformity in OAK were included by the clinicians in spite of a likelihood of complaining of pain over either medial or lateral aspects of the knee. People sitting on the floor as part of Japanese lifestyle might account for choice of these items.

This study aimed to clarify how clinical experience with patients influences pattern recognition. The object of this study was not to look into clinical features of specific musculoskeletal disorders. We hypothesized that (i) appreciation of subjective symptoms would change through clinical experience with patients and (ii) attention to objective aspects was influenced by the degree of appreciation of subjective symptoms. The results of this study accords with these hypotheses. Our findings suggest that students find it difficult to imagine specifically how patients are troubled, and that pattern recognition develops as a professional craft is updated via clinical experience. Clinical experience with patients is essential to promote illness scripts (21). This study corroborated the idea of development of illness scripts via clinical experience with real patients. The number of participants in Delphi studies varies, ranging by one account from 10 to more than 1500 people (26), yet this number is related to neither statistical sample size nor validity (10). The number of participants in this preliminary study fulfilled the minimum requirement specified in previous studies.

This study is limited in that we did not assess ability of pattern recognition among the physiotherapists or their degrees of experience in treating OAK or CFP. Although the findings of this study may pertain to pattern recognition of musculoskeletal disorders for physiotherapists, applicability to other clinical areas such as neurological or cardiovascular problems may merit separate study.

\section{Conclusion}

The necessity of clinical experience in developing illness descriptions of two musculoskeletal disorders was confirmed through use of a quasi-Delphi technique in comparing students with very limited clinical experience against seasoned clinicians. In portraying subjective aspects of the clinical conditions, the clinicians resorted more to colloquial descriptions than did the students. Our findings suggest that students find it difficult to imagine specifically how patients are troubled, and that pattern recognition develops as a professional craft is updated via clinical experience.

\section{Acknowledgement}

I would like to express my gratitude to all of the students and clinicians who were willing to participate in this study.

\section{Reference}

1. Schmidt HG, Norman GR, Boshuizen HPA. A cognitive perspective on medical expertise: theory and implications. Academic Medicine. 1990; 65: 611-621.

2. Charlin B, Tardif J, Boshuizen HPA. Scripts and medical diagnostic knowledge: theory and applications for clinical reasoning instruction and research. Academic Medicine. 2000; 75:182-90.

3. Bowen JL. Educational strategies to promote diagnostic reasoning. The New England Journal of Medicine. 2006; 355: 2217-2225.

4. Coderre S, Mandin H, Harasym PH, Fick GH. Diagnostic reasoning strategy and diagnostic success. Medical Education. 2003; 37: 695-703.

5. Charlin B, Boshuizen HPA, Custgers EJ, Feltovich PJ. Scripts and clinical reasoning. Medical Education. 2007; 41: 1178-1184.

6. Jones MA, Rivett DA. Introduction to clinical reasoning. In: Jones MA, Rivett DA, editors. Clinical Reasoning for Manual Therapists. Edinburgh: Butterworth Heinemann; 2004. p. 3-24.

7. Dalkey N, Helmer O. An experimental application of the Delphi method to the use of experts. Management Science. 1963; 9: 458-467.

8. Hsu CC, Sandford BA. The Delphi technique: making sense of consensus. Practical Assessment, Research \& Evaluation. 2007; 12: 1-8.

9. Binkley J, Finch E, Hall J, Black T, Gowland C. Diagnostic classification of 
patients with low back pain: report of a survey of physical therapy experts. Physical Therapy. 1993; 73:138-150.

10. Cook C, Brismée JM, Fleming R, Sizer PS. Identifiers suggestive of clinical cervical spine instability: a Delphi study of physical therapists. Physical Therapy. 2005; 85: 895906.

11. Cook C, Brismée JM, Sizer PS. Subjective and objective descriptors of clinical lumbar spine instability: A Delphi study. Manual Therapy. 2006; 11: 11-21.

12. Smart KM, Blake CB, Staines A, Doody C. Clinical indicators of 'nociceptive', 'peripheral neuropathic' and 'central' mechanisms of musculoskeleral pain. A Delphi survey of expert clinicians. Manual Therapy. 2010; 15: 80-87.

13. Walmsley S, Rivett DA, Osmotherly PG. Adhesive capsulitis: establishing consensus on clinical identifiers for stage 1 using the Delphi technique. Physical Therapy. 2009; 89: 906-917.

14. Wilde VE, Ford JJ, McMeeken JM. Indicators of lumbar zygapophyseal joint pain: survey of an expert panel with the Delphi technique. Physical Therapy. 2007; 87: 1348-1361.

15. Wainwright, SF, Shepard, KF, Harman, LB, Stephens, J. Novice and experienced physical therapist clinicians: a comparison of how reflection is used to inform the clinical decision-making process. Physical Therapy. 2010; 90(1): 1-14.

16. Papa FJ, Shores JH, Meyer S 1990. Effects of pattern matching, pattern discrimination, and experience in the development of diagnostic experience. Academic Medicine. 1990; 65 (9 Spuppl): S21-22.

17. Dunn, MM \& Woolliscroft, JO 1994. Assessment of a pattern-recognition examination in a clinical clerkship. Academic Medicine. 1994; 69 (8): 683-684.

18. Rowe G, Wright G. The Delphi technique as a forecasting tool: issues and analysis. International Journal of Forecasting. 1999; 15: 353-375.

19. Edwards I, Jones MA, Carr J, BraunackMayer A, Jensen GM. Clinical reasoning strategies in physical therapy. Physical Therapy. 2004; 84: 312-330.

20. May S, Greasley A, Reeve S, Withers S. Expert therapists use specific clinical reasoning process in the assessment and management of patients with shoulder pain' a qualitative study. Australian Journal of Physiotherapy. 2008; 54: 261-266.
21. Boshuizen HPA, Schmidt HG. The development of clinical reasoning expertise. In: Higgs J, Jones MA, Loftus S, Christensen N, editors. Clinical reasoning in the health professions. $3^{\text {rd }}$ ed. Edinburgh: Butterworth Heinemann; 2008. p. 113-121.

22. McAlindon TE, Cooper C, Kirwan JR, Dieppe PA. Determinants of disability in osteoarthritis of the knee. Annals of the Rheumatic Diseases. 1993; 52: 258-262.

23. Owen RA, Melton LJ, Johnson KA, Ilstrup DM, Riggs BL. Incidence of Colles' fracture in a North American community. American Journal of Public Health. 1982; 72: 605-607

24. Hagino $H$, Yamamoto $K$, Teshima $R$, Kishimoto H, Kuranobu K, Nakamura T. The incidence of fractures of the proximal femur and the distal radius in Tottori prefecture, Japan. Archives of Orthopaedic and Trauma Surgery. 1989; 109: 43-44.

25. Altizer LL. Colles' fracture. Orthopaedic Nursing. 2008; 27: 140-145.

26. Powell C. The Delphi technique: myths and realities. Methodological issues in nursing research. 2003; 41: 376-382. 